\title{
Increased serum CXCL1 and CXCL5 are linked to obesity, hyperglycemia, and impaired islet function
}

\author{
Craig S Nunemaker ${ }^{1}$, H Grace Chung ${ }^{1,2}$, Gretchen M Verrilli, ${ }^{1,3}$, Kathryn L Corbin', \\ Aditi Upadhye' and Poonam R Sharma' \\ ${ }^{1}$ Division of Endocrinology and Metabolism, Department of Medicine, ${ }^{2}$ Department of Biomedical Engineering and \\ ${ }^{3}$ Department of Biology, University of Virginia, PO Box 801413, Charlottesville, Virginia 22908, USA
}

Correspondence should be addressed to C S Nunemaker Email

nunemaker@virginia.edu

\begin{abstract}
Proinflammatory cytokines are thought to play a significant role in the pathogenesis of type 2 diabetes (T2D) and are elevated in the circulation even before the onset of the disease. However, the full complement of cytokines involved in the development of T2D is not known. In this study, 32 serum cytokines were measured from diabetes-prone BKS.Cg- $m+/+$ Lepr $^{d b} / J(\mathrm{db} / \mathrm{db})$ mice and heterozygous age-matched control mice at 5 weeks (non-diabetic/non-obese), 6-7 weeks (transitional-to-diabetes), or 11 weeks (hyperglycemic/ obese) and then correlated with body weight, blood glucose, and fat content. Among these 32 cytokines, C-X-C motif ligand 1 (CXCL1) showed the greatest increase $(+78 \%)$ in serum levels between $\mathrm{db} / \mathrm{db}$ mice that were hyperglycemic (blood glucose: $519 \pm 23 \mathrm{mg} / \mathrm{dl}, n=6$ ) and those that were non-hyperglycemic $(193 \pm 13 \mathrm{mg} / \mathrm{dl}, n=8)$. Similarly, increased CXCL1 $(+68 \%)$ and CXCL5 ( $+40 \%)$ were associated with increased obesity in $\mathrm{db} / \mathrm{db}$ mice; note that these effects could not be entirely separated from age. We then examined whether islets could be a source of these chemokines. Exposure to cytokines mimicking low-grade systemic inflammation ( $10 \mathrm{pg} / \mathrm{ml} \mathrm{IL1} \beta+20 \mathrm{pg} / \mathrm{ml}$ IL6) for $48 \mathrm{~h}$ upregulated islet CXCL1 expression by $53 \pm 3$-fold and CXCL5 expression by $83 \pm 10$-fold ( $n=4, P<0.001)$. Finally, overnight treatment with the combination of $\mathrm{CXCL1}$ and $\mathrm{CXCL5}$ at serum levels was sufficient to produce a significant decrease in the peak calcium response to glucose stimulation, suggesting reduced islet function. Our findings demonstrated that CXCL1 and CXCL5 i) are increased in the circulation with the onset of $\mathrm{T} 2 \mathrm{D}$, ii) are produced by islets under stress, and iii) synergistically affect islet function, suggesting that these chemokines participate in the pathogenesis of T2D.
\end{abstract}

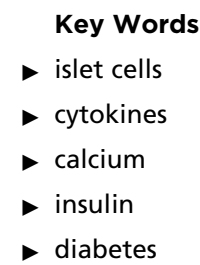

Journal of Endocrinology (2014) 222, 267-276

\section{Introduction}

Chronic low-grade inflammation is increasingly considered as a contributing factor to many metabolic diseases including type 2 diabetes (T2D). Obesity leads to excess fatty acids and lipids in the body, which have toxic and damaging effects on the body's metabolism (Paolisso et al. 1995, Poitout \& Robertson 2002, Robertson et al. 2004) and also cause low-grade systemic inflammation (Wellen \& Hotamisligil 2003). This inflammation, particularly of fat tissue, increases the circulating levels of proinflammatory cytokines in the blood. These cytokines 
contribute to the two defining characteristics of T2D: i) insulin resistance and ii) defective insulin secretion, which lead to hyperglycemia (Greenberg \& McDaniel 2002). Our hypothesis is that increased levels of circulating cytokines caused by obesity can have potentially damaging effects in distal tissues, such as the pancreatic islets of Langerhans. We have recently demonstrated that exposure to circulating levels of certain cytokines (interleukin $1 \beta$ (IL1B) and IL6 in combination) is sufficient to trigger dysfunction and apoptosis in islets from diabetesprone mice without significantly disrupting islet function in healthy mice (O'Neill et al. 2013).

Our objective in this study was to identify other circulating cytokines and chemokines associated with T2D that could also contribute to changes in normal islet function. We examined 32 different cytokines/ chemokines in serum from leptin-receptor-deficient $\mathrm{db} / \mathrm{db}$ mice during the development of diabetes in order to identify additional cytokines that could directly contribute to or protect against islet decline in T2D. We identified two chemokines of interest that increased in serum with the development of obesity and hyperglycemia: C-X-C motif ligand 1 (CXCL1) and CXCL5. Both CXCL1 and CXCL5 bind with the CXCR2 receptor and are associated with processes as diverse as angiogenesis, wound healing, and tumorigenesis. CXCL1 is expressed in macrophages, neutrophils, and epithelial cells, and it plays a key role in inflammation as a chemoattractant for neutrophils. CXCL5 is expressed in eosinophils as well as epithelial cells and has a well-established role in stimulating the chemotaxis of angiogenic neutrophils, particularly in response to inflammation.

CXCL1 and CXCL5 are also associated with diabetes. Increased serum levels of CXCL1 have been reported in patients with type 1 diabetes (Takahashi et al. 2011, Hakimizadeh et al. 2013) and more recently in T2D (Sajadi et al. 2013). Increased serum CXCL5 has also been observed in obesity and insulin resistance in mice and humans (Chavey et al. 2009), and it is associated with complications of diabetes including nephropathy (Higurashi et al. 2009) and atherosclerosis (Chen et al. 2011). CXCL1 has also been reported to be a CD40induced chemokine in isolated human pancreatic islets (Klein et al. 2008), which is also expressed in response to amyloid in T2D (Westwell-Roper et al. 2011). CXCL1 expression is associated with increased rates of islet transplant failure (Citro et al. 2012, Cowley et al. 2012), and blocking the CXCL1 receptor CXCR2 improves transplant outcomes (Citro et al. 2012). In this study, we demonstrated that both CXCL1 and CXCL5 increase in serum as diabetes-prone $\mathrm{db} / \mathrm{db}$ mice become obese and hyperglycemic. Further, we demonstrated for the first time that exposure to CXCL1 and CXCL5 at circulating levels can directly affect islet function and that islet cell stress can induce the expression of CXCL1 and CXCL5. Our findings together suggest a role for these chemokines in T2D both systemically and within the pancreatic islet.

\section{Materials and methods}

\section{Mice}

Studies of serum cytokine levels were conducted using male BKS.Cg-Dock $7^{m}+1+L e p r^{d b} / \mathrm{J}(\mathrm{db} / \mathrm{db})$ mice as a model of T2D, with age-matched heterozygous (het) mice as controls (Jackson Laboratories, Bar Harbor, ME, USA). Mice were used at ages of 5, 6-7, and 11 weeks. Follow-up studies of cytokine effects on normal pancreatic islets were conducted using outbred CD1 mice at ages of 8-12 weeks (Charles River Laboratories, Wilmington, MA, USA). All animal procedures were approved by the Institutional Animal Care and Use Committee at the University of Virginia (UVA).

\section{Dual-energy X-ray absorptiometry analysis}

DEXA scans were performed using a Lunar PixiMUS densitometer (GE Medical Systems, Waukesha, WI, USA) to determine fat and bone mineral content (BMC). Mice were anesthetized by i.p. injection of $20 \mathrm{mg} / \mathrm{ml}$ xylazine and $100 \mathrm{mg} / \mathrm{ml}$ ketamine in $0.9 \%$ sterile saline at a dose of $5 \mu \mathrm{l} / \mathrm{g}$ body weight and then placed on the Lunar PIXImus tray for scanning, as described previously (Roland et al. 2010). After running a quality control test, the animal was scanned to measure area, bone mineral density (BMD), BMC, lean body mass, fat body mass, total body mass, and percent body fat. Following the scan, mice were injected subcutaneously with $1 \mathrm{ml}$ of $0.9 \%$ sterile saline for hydration and then placed on a heating pad and monitored until recovery from anesthesia.

\section{Cytokine panel}

For this study, $34 \mathrm{db} / \mathrm{db}$ and 34 het mice varying in age from 5, 6-7, and 11 weeks old were killed by $\mathrm{CO}_{2}$. Blood was immediately collected by heart puncture, allowed to clot at room temperature, and then centrifuged to collect serum. Samples were frozen at $-20^{\circ} \mathrm{C}$ for long-term storage. Serum was thawed briefly to extract $60 \mu \mathrm{l}$ and shipped to Millipore, Inc. (St Charles, MO, USA) on dry ice for use in a 32-plex mouse cytokine assay. Samples were

Published by Bioscientifica Ltd. 
diluted 1:2 by Millipore and were run in singlet following the bead-based assay protocol.

\section{Islet isolation and treatment}

Pancreatic islets were isolated by collagenase-P digestion (Roche Diagnostics) followed by centrifugation with Histopaque 1100 (Sigma-Aldrich) as described previously (Carter et al. 2009). Islets were incubated overnight in RPMI 1640 medium (Invitrogen) supplemented with 10\% fetal bovine serum (FBS) and 1\% penicillin/streptomycin to allow recovery from collagenase digestion before further treatment. Various islet stressors were prepared as follows: rotenone and thapsigargin were purchased from SigmaAldrich and prepared in stocks of DMSO to final concentrations $<0.1 \%$. Glucose-free RPMI medium (10\% FBS and $1 \%$ penicillin/streptomycin) was supplemented with $1 \mathrm{M}$ glucose stock to produce the $28 \mathrm{G}$ condition. Stocks of the murine forms of IL1B, IL6, CXCL1, and CXCL5 (purchased from R\&D Systems, Inc., Minneapolis, MN, USA) were prepared in PBS with $0.1 \%$ BSA. Oleate, linoleate, and palmitate were purchased from Sigma-Aldrich and were prepared in $100 \mathrm{mM}$ stock concentrations in methanol and stored at $-80^{\circ} \mathrm{C}$. To treat the islets, required amount of each fatty acid was taken in a glass tube and dried under a stream of nitrogen to remove methanol. The dried mixture of fatty acids thus obtained was resuspended in the RPMI medium with $0.1 \%$ BSA followed by vortexing and sonication. All experiments were completed within $48-72 \mathrm{~h}$ after isolation.

\section{Glucose-stimulated calcium measurements}

Intracellular calcium $\left(\left[\mathrm{Ca}^{2+}\right]_{\mathrm{i}}\right)$ was measured using the ratiometric $\left[\mathrm{Ca}^{2+}\right]_{\mathrm{i}}$ indicator fura-2 $\mathrm{AM}$ as described previously (Crim et al. 2010, Corbin et al. 2011). Briefly, Cell Tracker Red CMTPX (CTR, Invitrogen), a membranepenetrating fluorescent probe, was used in order to distinguish cytokine-treated islets from control islets by selectively labeling only one of the two groups, thus enabling simultaneous comparison of the two treatment groups (see Corbin et al. (2011)) for additional details). All islets were loaded with $1 \mu \mathrm{M}$ fura- $2 \mathrm{AM}$ for $30 \mathrm{~min}$ in the presence or absence of $200 \mathrm{nM}$ CTR, washed, and then recorded using a Hamamatsu ORCA-ER camera (Hamamatsu Photonics, Hamamatsu, Japan) attached to an Olympus BX51WI fluorescence microscope (Olympus, Tokyo, Japan) using 340 and $380 \mathrm{~nm}$ excitation light and $510 \mathrm{~nm}$ emission as described previously (Jahanshahi et al. 2009). Data were recorded and analyzed using IP Lab software Version 4.0 (Scanalytics, Rockville, MD, USA).

\section{Glucose-stimulated insulin secretion}

After overnight incubation, islets were tested for insulin secretion as described previously (Crim et al. 2010). Briefly, islets were preincubated at $37^{\circ} \mathrm{C}$ in an atmosphere of $5 \%$ $\mathrm{CO}_{2}$ for $1 \mathrm{~h}$ in a standard $\mathrm{KRB}$ solution, then washed, and incubated in $\mathrm{KRB}$ supplemented with $3 \mathrm{mM}$ glucose for $1 \mathrm{~h}$ followed by treatment with KRB containing $11 \mathrm{mM}$ glucose for $1 \mathrm{~h}$. The supernatant was collected after each treatment and insulin concentration in the supernatant was measured by ELISA (Mercodia, Uppsala, Sweden) according to the manufacturer's instructions.

\section{Real-time PCR}

RNA was collected from islets treated with cytokines associated with low-grade inflammation (IL6+IL1 $\beta$ ). Untreated islets served as a control. RNA and cDNA preparation and real-time PCRs (RT-PCRs) were performed as described previously (O'Neill et al. 2013). RNA purity and concentration were determined using a Nanodrop spectrophotometer.

\section{Statistical analysis}

An unpaired two-tailed $t$-test was used to compare het and $\mathrm{db} / \mathrm{db}$ groups, with a $P$ value of $P<0.05$ used as an indication of statistical significance. All comparisons of serum cytokine levels assumed a minimum of four detectable samples. Cytokines with less than four detectable samples were considered undetectable for statistical evaluation.

\section{Results}

\section{Observed differences in weight, blood glucose, and body composition in $\mathrm{db} / \mathrm{db}$ mice}

We first measured body weight and blood glucose for $\mathrm{db} / \mathrm{db}$ mice and heterozygous controls at each of the key developmental stages of T2D $(5,6-7$, and 11 weeks). As shown in Fig. 1, db/db mice showed both increased body weight (Fig. 1A) and blood glucose (Fig. 1B) as early as 6-7 weeks of age. By 11 weeks, there was a more substantial difference in weight $(P<0.001)$ and blood glucose $(P<0.001)$ when compared with het mice. There were no significant differences in either parameter between het and $\mathrm{db} / \mathrm{db}$ mice at 5 weeks.

To further examine whether there could be more nuanced differences between strains in the early stages

Published by Bioscientifica Ltd. 

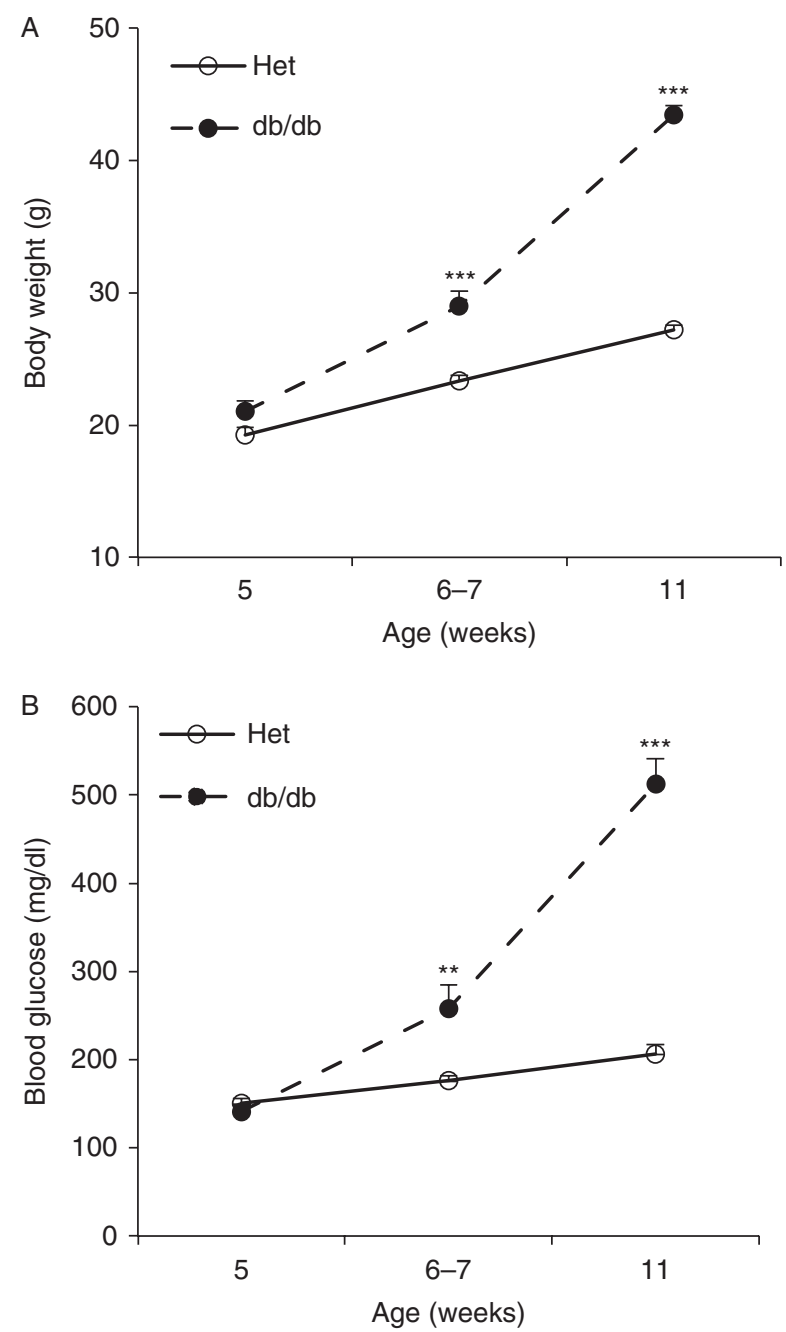

Figure 1

Compared with het mice, $\mathrm{db} / \mathrm{db}$ mice have progressively higher (A) body weight and (B) blood glucose with increasing age. ${ }^{* * P} P<0.01, * * * P<0.001$.

of disease progression, we examined body composition by DEXA for the 5-week-old mice only. As can be observed from Table 1, substantial differences in fat pads, BMC, and percent body fat were found between het and $\mathrm{db} / \mathrm{db}$ mice $(P<0.001)$. There were also variations in BMD $(P<0.01)$ and, to a lesser extent, lean body mass and body fat $(P<0.05)$. These differences in lean vs fat mass may account for the similarity in total body weight at this age.

\section{Serum cytokine differences between strains at each age}

Cytokine milieu differences between strains at various ages were very few. Among 32 cytokines tested, 12 were not detectable ( $n<4$ samples/strain) across all age groups. The remaining cytokines that could be evaluated showed no differences between $\mathrm{db} / \mathrm{db}$ and het at either $6-7$ or 11 weeks. The only statistical difference between strains was observed for serum IL1A from the 5-week-old mice. IL1A was $322 \pm 67 \mathrm{ng} / \mathrm{ml}$ in $\mathrm{db} / \mathrm{db}$ mice $(n=15)$ vs $574 \pm 86 \mathrm{ng} / \mathrm{ml}$ in het controls $(n=14, P=0.03)$.

\section{CXCL1 and CXCL5 associated with obesity and hyperglycemia}

We hypothesized that serum levels of cytokines might also vary within the diabetes-prone strain as the disease progresses to obesity and hyperglycemia. We thus made comparisons of serum cytokine levels between the most vs least obese $\mathrm{db} / \mathrm{db}$ mice or between the most vs least hyperglycemic $\mathrm{db} / \mathrm{db}$ mice. As there were no cases of hyperglycemia or obesity among the youngest mice, transition to diabetes in the 6-7- and 11-week-old groups was focused for analysis. As shown in Fig. 2A, serum levels of CXCL1 and CXCL5 were both higher in obese mice (body weight $>40 \mathrm{~g}, n=6$ ) compared with non-obese mice (body weight $<35 \mathrm{~g}, n=10, P<0.001$ ). Notably, as serum levels of different cytokines can differ by orders of magnitude, data are presented for cytokine levels in obese mice as a percent of the cytokine levels in nonobese controls. Scatter plots for CXCL1 and CXCL5 vs body weight are shown in Fig. $2 \mathrm{~B}$ and $\mathrm{C}$ respectively. As shown in Fig. 2D, serum levels of CXCL1 were similarly higher among hyperglycemic mice (blood glucose $>400 \mathrm{mg} / \mathrm{dl}, n=5$ ) compared with non-hyperglycemic mice (blood glucose $<250 \mathrm{mg} / \mathrm{dl}, n=8, P<0.001$ ). CXCL5 was increased as well, but not significantly $(P=0.098)$. Scatter plots for each chemokine vs blood glucose are shown in Fig. 2E and F. See also Supplementary Figure 1, see section on supplementary data given at the end of this article, for serum cytokine levels reported in $\mathrm{pg} / \mathrm{ml}$.

Table 1 Key body composition and dual-energy X-ray absorptiometry (DEXA) results for $\mathrm{db} / \mathrm{db}$ (pre-diabetic) and het mice at 5 weeks of age

Measurement
Weight $(\mathrm{g})$
Blood glucose $(\mathrm{mg} / \mathrm{dl})$
Fasting BG $(\mathrm{mg} / \mathrm{dl})$
Fat pads $(\mathrm{mg})^{\ddagger}$
BMD $\left(\mathrm{mg} / \mathrm{cm}^{2}\right)^{\dagger}$
BMC $(\mathrm{mg})^{\ddagger}$
Lean body mass $(\mathrm{g})^{*}$
Body fat $(\mathrm{g})^{*}$
$\%$ Body fat

\begin{tabular}{c}
\hline Heterozygous \\
\hline $20.7 \pm 0.9$ \\
$154 \pm 3$ \\
$146 \pm 5$ \\
$189 \pm 26$ \\
$35 \pm 1$ \\
$237 \pm 15$ \\
$15.8 \pm 0.7$ \\
$3.8 \pm 0.3$ \\
$19 \pm 1$
\end{tabular}

\begin{tabular}{c}
\hline $\mathbf{d b} / \mathbf{d b}$ \\
\hline $21.2 \pm 1.0$ \\
$182 \pm 28$ \\
$128 \pm 22$ \\
$620 \pm 57$ \\
$30 \pm 1$ \\
$136 \pm 6$ \\
$13.9 \pm 0.5$ \\
$6.6 \pm 0.7$ \\
$32 \pm 1$
\end{tabular}

${ }^{*} P<0.05,{ }^{\dagger} P<0.01,{ }^{\ddagger} P<0.001$. 

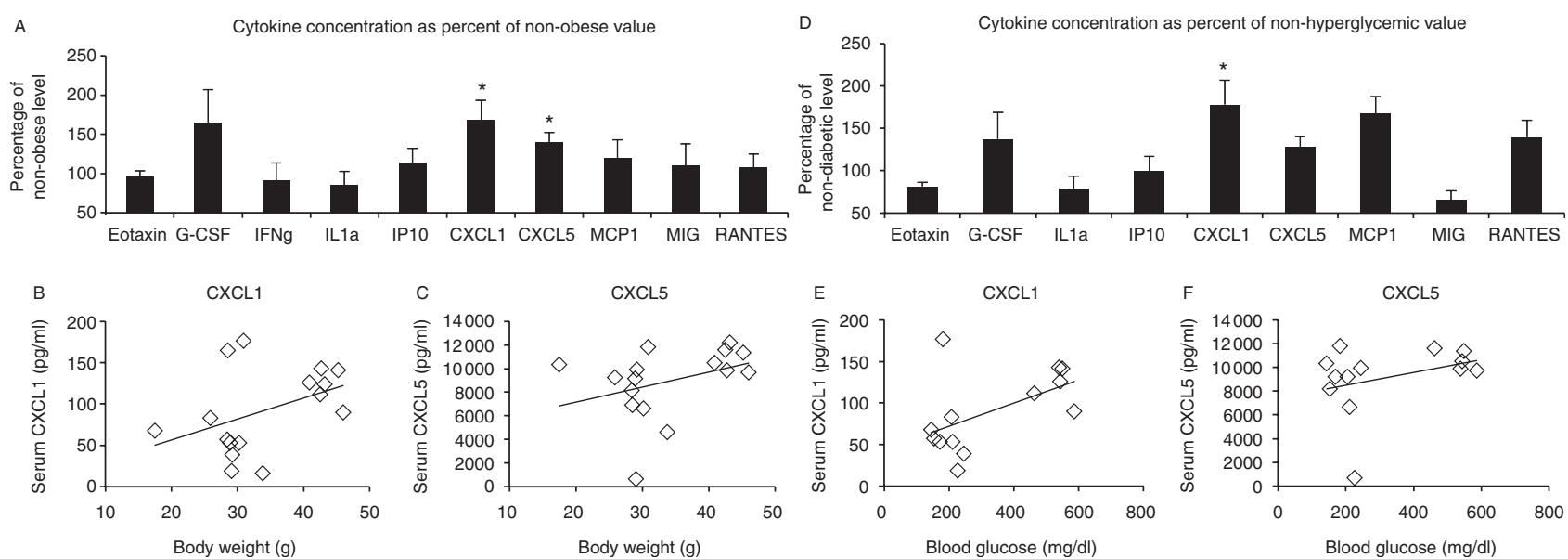

Figure 2

CXCL1 and CXCL5 are closely associated with obesity and hyperglycemia. (A) Serum levels of cytokines/chemokines in obese $\mathrm{db} / \mathrm{db}$ mice (body weight: $43.4 \pm 0.4 \mathrm{~g}, n=6$ mice) as a percent of non-obese controls (29.0 \pm $1.1 \mathrm{~g}, n=13$ mice). (B and C) Scatter plots of serum CXCL1 (B) and CXCL5 levels (C) vs body weight. (D) Serum levels of cytokines/chemokines in hyperglycemic db/db mice (blood glucose: $519 \pm 23 \mathrm{mg} / \mathrm{dl}, n=6$ mice) as

\section{Increased gene expression of $\mathrm{Cxcl} 1$ and $\mathrm{Cxcl} 5$ in pancreatic islets in response to cell stress}

We then examined various stressors hypothesized to trigger $\beta$-cell failure in T2D (Montane et al. 2014) for their effects on Cxcl1 and Cxcl5 gene expression. Islets from CD1 mice were exposed for $48 \mathrm{~h}$ to one of the following stressors: $20 \mathrm{nM}$ rotenone as a model of oxidative stress (Hoehn et al. 2009), $100 \mathrm{nM}$ thapsigargin as a model of ER stress (Eizirik et al. 2008), $10 \mathrm{pg} / \mathrm{ml} \mathrm{IL1} \beta+$ $20 \mathrm{pg} / \mathrm{ml}$ IL6 as a model of low-grade inflammation (cytokines; Spranger et al. (2003) and O'Neill et al. (2013)), $28 \mathrm{mM}$ glucose as a model of glucotoxicity (28G, Tang et al. (2012)), or free fatty acids (FFAs: $50 \mu \mathrm{M}$ palmitate $+100 \mu \mathrm{M}$ oleate $+50 \mu \mathrm{M}$ linoleate) as a model of lipotoxicity (Watt et al. 2012). Islets incubated in standard RPMI 1640 media containing 10\% FBS and 1\% penicillin/streptomycin were used as controls. As shown in Fig. 3, we found that cytokine treatment substantially stimulated Cxcl1 ( 50-fold increase, $P<0.001)$ and $C x c l 5$ expression ( $\sim 80$-fold, $P<0.001)$. Thapsigargin also appeared to consistently stimulate Cxcl1 expression (Fig. 3A), but the degree of stimulation was highly variable across trials and did not reach significance (3.7-, 7.8-, 16.5, and 55.5-fold increase; $P=0.14$ ). As shown in Fig. 3B, thapsigargin-induced $C x c l 5$ expression showed a similar variability (2.3-, 11.8-, 23.6-, and 44.0-fold increase; $P=0.07)$. FFA treatment also mildly, but significantly,

a percent of non-hyperglycemic controls ( $193 \pm 13 \mathrm{mg} / \mathrm{dl}, n=8 \mathrm{mice})$. ( $E$ and F) Scatter plots of serum CXCL1 (E) and CXCL5 levels (F) vs blood glucose. ${ }^{*} P<0.05$. See Supplementary Table 1 , see section on supplementary data given at the end of this article, for cytokine/ chemokine values expressed in $\mathrm{pg} / \mathrm{ml}$.

upregulated $\mathrm{Cxcl5}$ expression by approximately eightfold (Fig. 3B, $P<0.05$ ). Overall, exposure to low-dose cytokines had the most robust effect on $\mathrm{Cxcl} 1$ and $\mathrm{Cxcl} 5$ expression, suggesting that the downstream effects of low-grade inflammation may be mediated, at least in part, by these chemokines.

\section{Combined effect of CXCL1 and CXCL5 on islet function}

We have previously shown that circulating levels of proinflammatory cytokines could directly affect islet function (O'Neill et al. 2013). We thus examined whether CXCL1 and CXCL5 could have a direct impact on pancreatic islet function at concentrations consistent with serum levels. Pancreatic islets were treated overnight with individual dosages of $100 \mathrm{pg} / \mathrm{ml} \mathrm{CXCL1,} 10 \mathrm{ng} / \mathrm{ml}$ CXCL5, both, or neither of them; these doses approximate the serum levels measured in the 32-plex cytokine panel. Islet function was then assessed by glucose-stimulated insulin secretion. As shown in Fig. 4A, we did not observe any significant differences in insulin release during incubation in low $(3 \mathrm{mM})$ glucose among treatment groups, although there was a slight tendency for more insulin release among chemokine-treated islets compared with untreated controls (not significant, $P>0.25$ ). Chemokines also had no effect on insulin secretion in stimulatory glucose $(11 \mathrm{mM})$ conditions (Fig. 4B). This lack of effect on insulin release is not necessarily

Published by Bioscientifica Ltd 

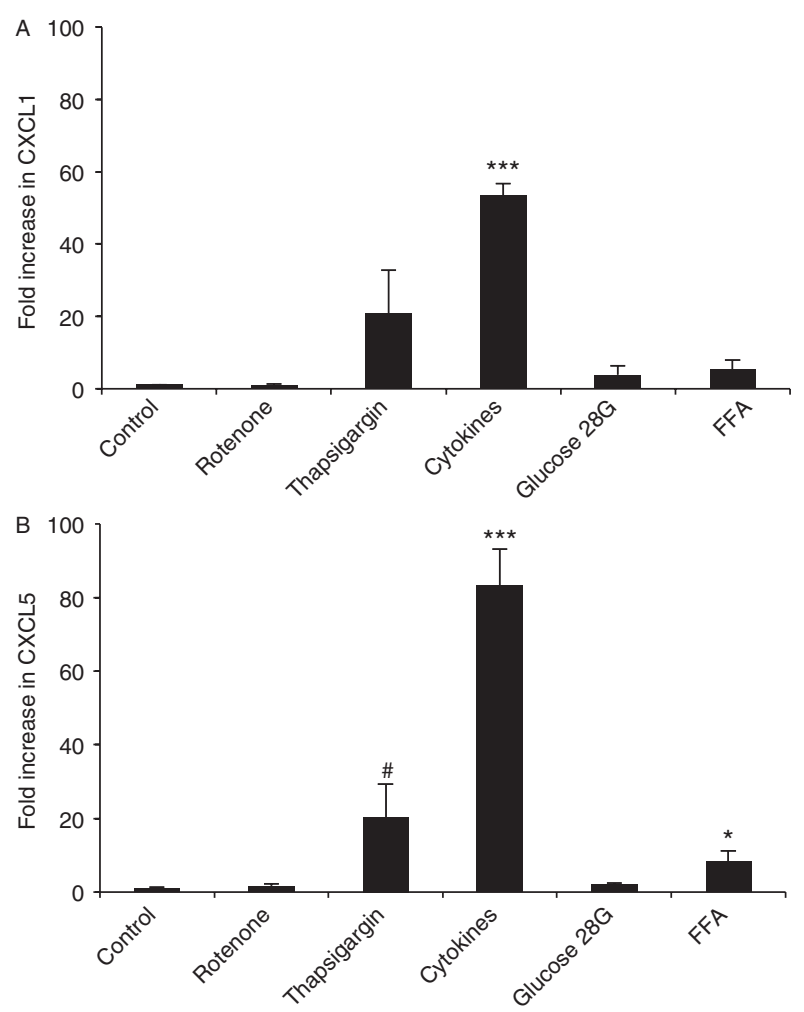

Figure 3

Induction of CXCL1 and CXCL5 after treatment with various cell stressors. (A) CXCL1 and (B) CXCL5 expression in CD1 islets following $48 \mathrm{~h}$ treatment with $20 \mathrm{nM}$ rotenone, $100 \mathrm{nM}$ thapsigargin, $10 \mathrm{pg} / \mathrm{ml} \mathrm{IL} 1 \beta+20 \mathrm{pg} / \mathrm{ml}$ IL6 (cytokines), $28 \mathrm{mM}$ glucose (Glucose 28G), or free fatty acids (FFAs):

$50 \mu \mathrm{g} / \mathrm{ml}$ palmitate $+100 \mu \mathrm{g} / \mathrm{ml}$ oleate $+50 \mu \mathrm{g} / \mathrm{ml}$ linoleate. Islets incubated in RPMI 1640 medium for $48 \mathrm{~h}$ were used as controls. $n=4$ independently isolated sets of islets for each condition (note that one outlier was removed from the 28G set for CXCL5). ${ }^{\#} P<0.10, * P<0.05, * * * P<0.001$ by two-tailed $t$-test. Error bars represent S.E.M.

surprising. We have previously shown that other proinflammatory cytokines in combination at low levels do not significantly affect insulin release in normal healthy islets, but they do disrupt calcium handling (Dula et al. 2010, O’Neill et al. 2013).

We then examined islet calcium responses to glucose stimulation following overnight exposure to $100 \mathrm{pg} / \mathrm{ml}$ CXCL1, $10 \mathrm{ng} / \mathrm{ml}$ CXCL5, both chemokines, or neither of them. As shown in Fig. 5A, overnight exposure to CXCL1 had no effect on basal calcium ( $3 \mathrm{mM}$ glucose), the phase 1 response to glucose stimulation (also called the peak response) or the phase 2 response (also called the plateau). As shown in Fig. 5B, overnight exposure to CXCL5 similarly had no effect on intracellular calcium. As both CXCL1 and CXCL5 bind to the same receptor, CXCR2, we hypothesized that these two chemokines could have a synergistic effect. As shown in Fig. 5C, combined treatment of $100 \mathrm{pg} / \mathrm{ml} \mathrm{CXCL1}$ and $10 \mathrm{ng} / \mathrm{ml}$ CXCL5 resulted in a significant decrease in the peak calcium response to glucose stimulation. The peak calcium response to glucose stimulation was reduced by $\sim 40 \%$ (Fig. $5 \mathrm{D}, P<0.01$ ) and the sustained plateau response by $\sim 15 \%$ among six trials (Fig. $4 \mathrm{D}, P<0.05$ ). This supports our hypothesis, suggesting that the presence of both serum CXCL1 and CXCL5 is necessary to affect islet function.

\section{Discussion}

In this study, we provide evidence that CXCL1 and CXCL5 are central to low-grade systemic inflammation associated with islet decline in T2D. We showed that i) only CXCL1 and CXCL5 were significantly associated with the onset of obesity and hyperglycemia in serum panel measurements of 32 cytokines/chemokines, ii) cytokine-induced stress in turn induced substantial
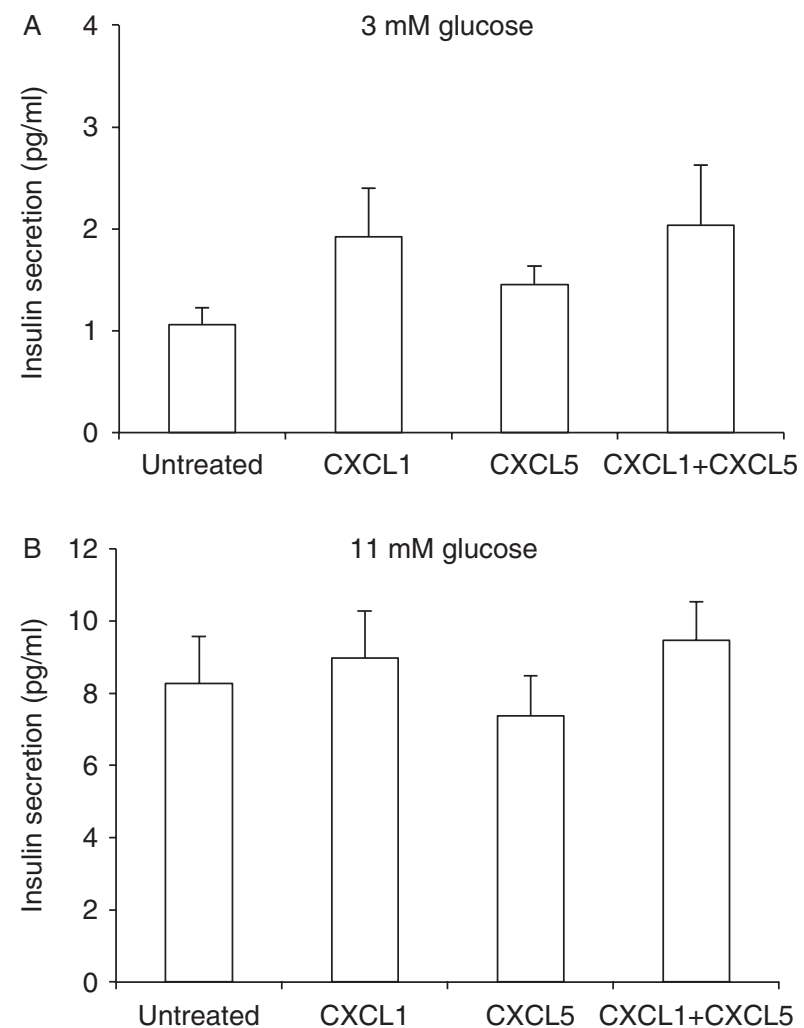

Figure 4

CXCL1 and CXCL5 do not affect insulin secretion. (A) Insulin secretion from islets in low (3 $\mathrm{mM})$ glucose following overnight incubation in one of the following conditions: untreated, $100 \mathrm{pg} / \mathrm{ml} \mathrm{CXCL1}, 10 \mathrm{ng} / \mathrm{ml} \mathrm{CXCL5}$, or both CXCL1 and CXCL5. (B) Insulin secretion from the same islets exposed to $11 \mathrm{mM}$ glucose. Sets of 20 islets were used for each condition ( $n=9$ replicate sets of islets per condition). No significant differences were observed.

Published by Bioscientifica Ltd. 

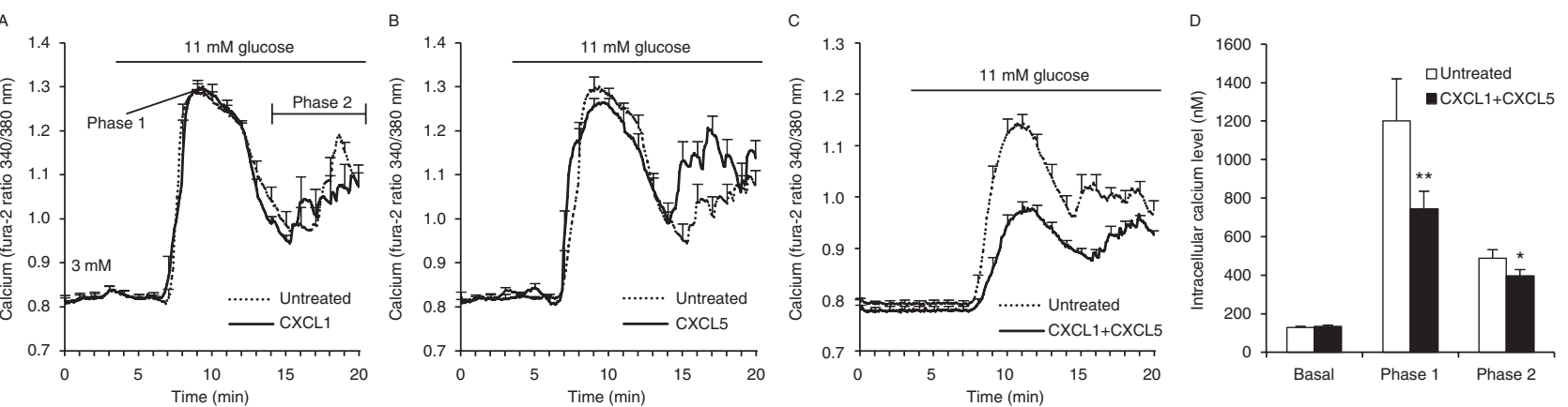

Figure 5

Synergistic effect of CXCL1 and CXCL5. Representative traces of glucosestimulated calcium (GSCa) responses for islets treated overnight with (A) $100 \mathrm{pg} / \mathrm{ml} \mathrm{CXCL1}(n=5)$ vs untreated controls $(n=7),(B) 10 \mathrm{ng} / \mathrm{ml} \mathrm{CXCL5}$ $(n=8)$ vs untreated controls $(n=6)$, or (C) both CXCL1 and CXCL5 $(n=11)$ vs untreated controls $(n=10)$. Each panel shows islets recorded from one of at

upregulation of Cxcl1 and Cxcl5 expression in islets, and iii) overnight exposure to CXCL1 and CXCL5 together could disrupt normal islet function. Collectively, these data suggest that these chemokines play a role both in systemic inflammation as evidenced by the increased levels in serum and in the inflammatory response within the islet itself.

The primary source of proinflammatory cytokines in obesity is adipose tissue. Both resident immune cells in adipose tissue and adipocytes themselves can contribute to the increase in circulating cytokines. Among 32 cytokines/chemokines tested in mouse serum, only CXCL1 and CXCL5 were positively correlated with the development of obesity and hyperglycemia. Our data are consistent with other studies showing that high-fat diet can increase CXCL1 levels in adipose tissue (Oliveira et al. 2013) and that serum CXCL5 is elevated in serum of human obese individuals compared with lean individuals (Chavey et al. 2009). Conversely, CXCL5 concentration is decreased in obese subjects following weight loss (Chavey et al. 2009, Kovacikova et al. 2011). We demonstrated that exposure to low-dose proinflammatory cytokines causes substantial upregulation of $C x c l 1$ and $C x c l 5$ mRNA in islet tissue, suggesting that islets may also be a source of CXCL1 and CXCL5.

It should be noted that we cannot exclude age as a factor driving our observed changes in chemokine levels in $\mathrm{db} / \mathrm{db}$ mice. However, there are reasons to favor the hypothesis that these chemokines are associated with obesity and hyperglycemia, more so than age alone. First, although most obese/hyperglycemic mice were of 11 weeks of age, one diabetic mouse came from the 6-7week age group and one 11-week-old mouse was not included in the obese or hyperglycemic category. Some least three trials conducted per treatment. (D) Mean values (calculated in $\mathrm{nM}$ ) for basal calcium, phase 1 (peak), and phase 2 (plateau) responses to glucose stimulation for islets treated overnight with $100 \mathrm{pg} / \mathrm{ml} \mathrm{CXCL1+}$ $10 \mathrm{ng} / \mathrm{ml} \mathrm{CXCL5}(n=36)$ compared with untreated islets $(n=42)$. Six trials were conducted in total. ${ }^{\star} P<0.05, * * P<0.01$.

mice were also excluded from analysis because they fell between the two cutoff points for normal blood glucose vs hyperglycemia. Secondly, similar associations between blood glucose and CXCL1 were found with similar stratified analyses for heterozygous controls. We observed six mice (two at 6-7 weeks and four at 11 weeks of age) that had non-fasted blood glucose levels of $210-250 \mathrm{mg} / \mathrm{dl}$, which we compared with 9 mice with blood glucose levels $<175 \mathrm{mg} / \mathrm{dl}$. CXCL1 levels were nearly significantly higher $(P=0.056)$ in mice with the higher blood glucose level. However, differences were not observed for CXCL5. A similar analysis in heterozygous mice was not possible for body weight because weight differences were small and entirely age dependent. Thirdly, our data are consistent with other groups that have reported a relationship between these chemokines and obesity, insulin resistance, and T2D (Chavey et al. 2009, Westwell-Roper et al. 2011, Oliveira et al. 2013, Sajadi et al. 2013), for which age was not a factor.

Our data, whether derived from fat tissue, islets, immune cells, or other sources, suggest that CXCL1 and CXCL5 can directly affect islet function. Although neither CXCL1 nor CXCL5 alone appeared to affect islets, overnight exposure to both CXCL1 and CXCL5 at concentrations detected in serum significantly reduced the calcium response to glucose stimulation, a key component of the stimulus-secretion pathway for insulin (Straub \& Sharp 2002, Ramadan et al. 2011). As CXCL1 and CXCL5 both bind to the chemokine receptor CXCR2, it is possible that both ligands are required to activate CXCR2 to produce downstream effectors that act on islet cells. Ours is the first evidence that these chemokines can directly affect islet function.

Published by Bioscientifica Ltd. 
Whether the primary purpose of CXCL1 and CXCL5 in islets is to initiate an immune response or to modify islet activity remains an open question. Many endocrine tissues, including the endocrine cells within pancreatic islets, have been shown to express the CXCR2 receptor (Tecimer et al. 2000), leaving open the possibility that the effects of these chemokines are mediated in an autocrine or paracrine manner entirely within the islet. Blockade of the CXCR1/2 pathway improved islet engraftment in mouse and human transplant recipients, and blockade also reduced recruitment of leukocytes and NKT cells to the site of the islet graft in mice (Citro et al. 2012). These findings suggest that blocking CXCR2 directly reduces inflammatory responses, but the improved islet engraftment could also be the due effects of blockade within the islet improving islet function. In a cyclophosphamideinduced transgenic mouse model of type 1 diabetes, marked upregulation of both CXCL1 and CXCL5 was thought to derive from inside the inflammatory infiltrate, not the islet cells themselves, suggesting primarily an immune-mediated response (Matos et al. 2004). Our findings suggest that CXCL1 and CXCL5 can synergistically inhibit the function of islets in vitro, where the islets are isolated from immune input. However, various resident immune cells, particularly macrophages, have been observed in isolated islets (Boni-Schnetzler et al. 2008), hence we cannot rule out these possible effects.

Regarding the regulation of CXCL1 and CXCL5 within islets, we examined a number of stressors that are hypothesized to trigger islet decline and failure in T2D (Donath et al. 2005). The combination of IL1 $\beta$ and IL6 at the low levels associated with low-grade inflammation had by far and away the strongest effect on $\mathrm{Cxcl1}$ and $\mathrm{Cxcl5}$ gene expression. This is because IL1 $\beta$ has been previously shown to upregulate Cxcl1 and this upregulation is dependent upon activation of NFkB (a target of IL1 $\beta$ signaling) and STAT signaling (associated with IL6) (Burke et al. 2014). Increased circulating levels of IL1B and IL6 are associated with an increased risk of T2D (Spranger et al. 2003), and we have shown previously that circulating levels of these cytokines can increase islet dysfunction and apoptosis in islets from diabetes-prone mice ( $\mathrm{O}^{\prime}$ Neill et al. 2013). We also observed in this study that exposure to FFAs upregulated Cxcl5 (and Cxcl1 to a minor extent), which is consistent with palmitate-induced CXCL1 expression observed in human islets (Igoillo-Esteve et al. 2010). Finally, thapsigargin-induced ER stress also appeared to upregulate Cxcl1 and Cxcl5, though the degree of upregulation was highly variable from trial to trial. This is intriguing as silencing of the transcription factor C/EBPdelta has been linked to increased Cxcl1 expression and increased Ddit3 expression (also known as CHOP, a key proapoptotic factor in ER stress) in rat islets and $\beta$-cell lines (Moore et al. 2012).

CXCL1 and CXCL5 are thus highly sensitive to low levels of inflammation in islets, and these same chemokines appear to be capable of synergistically affecting islet function. Our data suggest that CXCL1 and CXCL5 are markers of islet dysfunction, and they may be key instigators of islet failure in T2D. More work is required to determine why inflammation causes such strong upregulation of CXCL1 and CXCL5 in islets and to determine whether CXCL1 and CXCL5 act on endocrine cells, immune cells, and/or other cell types within the islet to inhibit islet function.

\section{Supplementary data}

This is linked to the online version of the paper at http://dx.doi.org/10.1530/ JOE-14-0126.

Declaration of interest

The authors declare that there is no conflict of interest that could be perceived as prejudicing the impartiality of the research reported.

\section{Funding}

This work was supported by the National Institutes of Health K01 DK081621 and R01 DK089182 to C S N.

\section{Author contribution statement}

C S N wrote the manuscript, designed experiments, acquired and analyzed data, edited the manuscript, and provided funding. C S N is a guarantor of this article and, as such, has full access to all the data in the study and takes responsibility for the integrity and accuracy of the data. H G C acquired and analyzed data, and edited the manuscript. G $\mathrm{M} \mathrm{V}$ acquired and analyzed data. K L C acquired data. A U acquired data and edited the manuscript. P R S acquired and analyzed data, and developed methods.

\section{Acknowledgements}

Mouse islets were acquired through the UVA Cell and Islet Isolation Core facility. The authors would like to thank Dr Susanna Keller and Stefan Hargett in the UVA Diabetes Center Animal Characterization Core for performing the DEXA and analyzing the data.

\section{References}

Boni-Schnetzler M, Ehses JA, Faulenbach M \& Donath MY 2008 Insulitis in type 2 diabetes. Diabetes, Obesity \& Metabolism 10(Suppl 4) 201-204. (doi:10.1111/j.1463-1326.2008.00950.x)

Burke SJ, Lu D, Sparer TE, Masi T, Goff MR, Karlstad MD \& Collier JJ 2014 $\mathrm{NF}-\kappa \mathrm{B}$ and STAT1 control CXCL1 and CXCL2 gene transcription. http://joe.endocrinology-journals.org DOI: 10.1530/JOE-14-0126
() 2014 Society for Endocrinology Printed in Great Britain
Published by Bioscientifica Ltd. 
American Journal of Physiology. Endocrinology and Metabolism 306 E131-E149. (doi:10.1152/ajpendo.00347.2013)

Carter JD, Dula SB, Corbin KL, Wu R \& Nunemaker CS 2009 A practical guide to rodent islet isolation and assessment. Biological Procedures Online 11 3-31. (doi:10.1007/s12575-009-9021-0)

Chavey C, Lazennec G, Lagarrigue S, Clape C, Iankova I, Teyssier J, Annicotte JS, Schmidt J, Mataki C, Yamamoto H et al. 2009 CXC ligand 5 is an adipose-tissue derived factor that links obesity to insulin resistance. Cell Metabolism 9 339-349. (doi:10.1016/j.cmet. 2009.03.002)

Chen L, Yang Z, Lu B, Li Q, Ye Z, He M, Huang Y, Wang X, Zhang Z, Wen J et al. 2011 Serum CXC ligand 5 is a new marker of subclinical atherosclerosis in type 2 diabetes. Clinical Endocrinology 75 766-770. (doi:10.1111/j.1365-2265.2011.04119.x)

Citro A, Cantarelli E, Maffi P, Nano R, Melzi R, Mercalli A, Dugnani E, Sordi V, Magistretti P, Daffonchio L et al. 2012 CXCR1/2 inhibition enhances pancreatic islet survival after transplantation. Journal of Clinical Investigation 122 3647-3651. (doi:10.1172/JCI63089)

Corbin KL, Hall TE, Haile R \& Nunemaker CS 2011 A novel fluorescence imaging approach for comparative measurements of pancreatic islet function in vitro. Islets 3 14-20. (doi:10.4161/isl.3.1.14133)

Cowley MJ, Weinberg A, Zammit NW, Walters SN, Hawthorne WJ, Loudovaris T, Thomas H, Kay T, Gunton JE, Alexander SI et al. 2012 Human islets express a marked proinflammatory molecular signature prior to transplantation. Cell Transplantation 21 2063-2078. (doi:10.3727/096368911X627372)

Crim WS, Wu R, Carter JD, Cole BK, Trace AP, Mirmira RG, Kunsch C, Nadler JL \& Nunemaker CS 2010 AGI-1067, a novel antioxidant and anti-inflammatory agent, enhances insulin release and protects mouse islets. Molecular and Cellular Endocrinology 323 246-255. (doi:10.1016/ j.mce.2010.02.041)

Donath MY, Ehses JA, Maedler K, Schumann DM, Ellingsgaard H, Eppler E \& Reinecke M 2005 Mechanisms of $\beta$-cell death in type 2 diabetes. Diabetes 54(Suppl 2) S108-S113. (doi:10.2337/diabetes.54.suppl_2.S108)

Dula SB, Jecmenica M, Wu R, Jahanshahi P, Verrilli GM, Carter JD, Brayman KL \& Nunemaker CS 2010 Evidence that low-grade systemic inflammation can induce islet dysfunction as measured by impaired calcium handling. Cell Calcium 48 133-142. (doi:10.1016/j.ceca.2010. 07.007)

Eizirik DL, Cardozo AK \& Cnop M 2008 The role for endoplasmic reticulum stress in diabetes mellitus. Endocrine Reviews 29 42-61. (doi:10.1210/er. 2007-0015)

Greenberg AS \& McDaniel ML 2002 Identifying the links between obesity, insulin resistance and $\beta$-cell function: potential role of adipocytederived cytokines in the pathogenesis of type 2 diabetes. European Journal of Clinical Investigation 32(Suppl 3) 24-34. (doi:10.1046/j.13652362.32.s3.4.x)

Hakimizadeh E, Shamsizadeh A, Nazari M, Arababadi MK, Rezaeian M, Vazirinejad R, Jamali Z, Poor NM, Khorramdelazad H, Darakhshan S et al. 2013 Increased circulating levels of CXC chemokines is correlated with duration and complications of the disease in type- 1 diabetes: a study on Iranian diabetic patients. Clinical Laboratory 59 531-537.

Higurashi M, Ohya Y, Joh K, Muraguchi M, Nishimura M, Terawaki H, Yagui K, Hashimoto N, Saito Y \& Yamada K 2009 Increased urinary levels of CXCL5, CXCL8 and CXCL9 in patients with type 2 diabetic nephropathy. Journal of Diabetes and its Complications 23 178-184. (doi:10.1016/j.jdiacomp.2007.12.001)

Hoehn KL, Salmon AB, Hohnen-Behrens C, Turner N, Hoy AJ, Maghzal GJ, Stocker R, Van Remmen H, Kraegen EW, Cooney GJ et al. 2009 Insulin resistance is a cellular antioxidant defense mechanism. PNAS 106 17787-17792. (doi:10.1073/pnas.0902380106)

Igoillo-Esteve M, Marselli L, Cunha DA, Ladriere L, Ortis F, Grieco FA, Dotta F, Weir GC, Marchetti P, Eizirik DL et al. 2010 Palmitate induces a proinflammatory response in human pancreatic islets that mimics CCL2 expression by $\beta$ cells in type 2 diabetes. Diabetologia 53 1395-1405. (doi:10.1007/s00125-010-1707-y)
Jahanshahi P, Wu R, Carter JD \& Nunemaker CS 2009 Evidence of diminished glucose stimulation and endoplasmic reticulum function in nonoscillatory pancreatic islets. Endocrinology 150 607-615. (doi:10.1210/en.2008-0773)

Klein D, Timoneri F, Ichii H, Ricordi C \& Pastori RL 2008 CD40 activation in human pancreatic islets and ductal cells. Diabetologia 51 1853-1861. (doi:10.1007/s00125-008-1092-y)

Kovacikova M, Sengenes C, Kovacova Z, Siklova-Vitkova M, Klimcakova E, Polak J, Rossmeislova L, Bajzova M, Hejnova J, Hnevkovska Z et al. 2011 Dietary intervention-induced weight loss decreases macrophage content in adipose tissue of obese women. International Journal of Obesity 35 91-98. (doi:10.1038/ijo.2010.112)

Matos M, Park R, Mathis D \& Benoist C 2004 Progression to islet destruction in a cyclophosphamide-induced transgenic model: a microarray overview. Diabetes 53 2310-2321. (doi:10.2337/diabetes.53.9.2310)

Montane J, Cadavez L \& Novials A 2014 Stress and the inflammatory process: a major cause of pancreatic cell death in type 2 diabetes. Diabetes, Metabolic Syndrome and Obesity : Targets and Therapy $725-34$. (doi:10.2147/DMSO.S37649)

Moore F, Santin I, Nogueira TC, Gurzov EN, Marselli L, Marchetti P \& Eizirik DL 2012 The transcription factor C/EBP delta has anti-apoptotic and anti-inflammatory roles in pancreatic $\beta$ cells. PLOS ONE 7 e31062. (doi:10.1371/journal.pone.0031062)

Oliveira MC, Menezes-Garcia Z, Henriques MC, Soriani FM, Pinho V, Faria AM, Santiago AF, Cara DC, Souza DG, Teixeira MM et al. 2013 Acute and sustained inflammation and metabolic dysfunction induced by high refined carbohydrate-containing diet in mice. Obesity 21 E396-E406. (doi:10.1002/oby.20230)

O'Neill CM, Lu C, Corbin KL, Sharma PR, Dula SB, Carter JD, Ramadan JW, Xin W, Lee JK \& Nunemaker CS 2013 Circulating levels of IL-1B + IL-6 cause ER stress and dysfunction in islets from prediabetic male mice. Endocrinology 154 3077-3088. (doi:10.1210/en.2012-2138)

Paolisso G, Gambardella A, Amato L, Tortoriello R, D'Amore A, Varricchio M \& D'Onofrio F 1995 Opposite effects of short- and long-term fatty acid infusion on insulin secretion in healthy subjects. Diabetologia $\mathbf{3 8}$ 1295-1299. (doi:10.1007/BF00401761)

Poitout V \& Robertson RP 2002 Minireview: secondary $\beta$-cell failure in type 2 diabetes - a convergence of glucotoxicity and lipotoxicity. Endocrinology 143 339-342. (doi:10.1210/endo.143.2.8623)

Ramadan JW, Steiner SR, O'Neill CM \& Nunemaker CS 2011 The central role of calcium in the effects of cytokines on $\beta$-cell function: implications for type 1 and type 2 diabetes. Cell Calcium 50 481-490. (doi:10.1016/j.ceca.2011.08.005)

Robertson RP, Harmon J, Tran PO \& Poitout V $2004 \beta$-cell glucose toxicity, lipotoxicity, and chronic oxidative stress in type 2 diabetes. Diabetes 53(Suppl 1) S119-S124. (doi:10.2337/diabetes.53.2007.S119)

Roland AV, Nunemaker CS, Keller SR \& Moenter SM 2010 Prenatal androgen exposure programs metabolic dysfunction in female mice. Journal of Endocrinology 207 213-223. (doi:10.1677/JOE-10-0217)

Sajadi SM, Khoramdelazad H, Hassanshahi G, Rafatpanah H, Hosseini J, Mahmoodi M, Arababadi MK, Derakhshan R, Hasheminasabzavareh R, Hosseini-Zijoud SM et al. 2013 Plasma levels of CXCL1 (GRO- $\alpha$ ) and CXCL10 (IP-10) are elevated in type 2 diabetic patients: evidence for the involvement of inflammation and angiogenesis/angiostasis in this disease state. Clinical Laboratory 59 133-137.

Spranger J, Kroke A, Mohlig M, Hoffmann K, Bergmann MM, Ristow M, Boeing H \& Pfeiffer AF 2003 Inflammatory cytokines and the risk to develop type 2 diabetes: results of the prospective population-based European prospective investigation into cancer and nutrition (EPIC)potsdam study. Diabetes 52 812-817. (doi:10.2337/diabetes.52.3.812)

Straub SG \& Sharp GW 2002 Glucose-stimulated signaling pathways in biphasic insulin secretion. Diabetes/Metabolism Research and Reviews 18 451-463. (doi:10.1002/dmrr.329)

Takahashi K, Ohara M, Sasai T, Homma H, Nagasawa K, Takahashi T, Yamashina M, Ishii M, Fujiwara F, Kajiwara T et al. 2011 Serum CXCL1 concentrations are elevated in type 1 diabetes mellitus, 
possibly reflecting activity of anti-islet autoimmune activity. Diabetes/Metabolism Research and Reviews 27 830-833. (doi:10.1002/ dmrr.1257)

Tang C, Koulajian K, Schuiki I, Zhang L, Desai T, Ivovic A, Wang P, Robson-Doucette C, Wheeler MB, Minassian B et al. 2012 Glucoseinduced $\beta$ cell dysfunction in vivo in rats: link between oxidative stress and endoplasmic reticulum stress. Diabetologia 55 1366-1379. (doi:10.1007/s00125-012-2474-8)

Tecimer T, Dlott J, Chuntharapai A, Martin AW \& Peiper SC 2000 Expression of the chemokine receptor CXCR2 in normal and neoplastic neuroendocrine cells. Archives of Pathology \& Laboratory Medicine 124 $520-525$.
Watt MJ, Hoy AJ, Muoio DM \& Coleman RA 2012 Distinct roles of specific fatty acids in cellular processes: implications for interpreting and reporting experiments. American Journal of Physiology. Endocrinology and Metabolism 302 E1-E3. (doi:10.1152/ajpendo.00418.2011)

Wellen KE \& Hotamisligil GS 2003 Obesity-induced inflammatory changes in adipose tissue. Journal of Clinical Investigation 112 1785-1788. (doi:10.1172/JCI20514)

Westwell-Roper C, Dai DL, Soukhatcheva G, Potter KJ, van Rooijen N, Ehses JA \& Verchere CB 2011 IL-1 blockade attenuates islet amyloid polypeptide-induced proinflammatory cytokine release and pancreatic islet graft dysfunction. Journal of Immunology 187 2755-2765. (doi:10.4049/jimmunol.1002854)

Received in final form 25 April 2014

Accepted 11 June 2014

Accepted Preprint published online 13 June 2014
Published by Bioscientifica Ltd. 